\title{
PENGARUH PENGETAHUAN REMAJA TENTANG NAPZA DAN HIV SERTA PENGETAHUAN ORANG TUA TENTANG PROGRAM PEMBANGUNAN KELUARGA TERHADAP PERILAKU PENGGUNAAN NAPZA PADA REMAJA
}

\author{
Sri Lilestina Nasution ${ }^{1}$, Herien Puspitawati $\left.{ }^{*}\right)$, Risda Rizkillah ${ }^{2}$, Mardiana Dwi Puspitasari ${ }^{1}$ \\ ${ }^{1}$ Pusat Penelitian dan Pengembangan KB dan KS, Badan Kependudukan dan Keluarga Berencana Nasional, \\ JI. Permata 1 No.1 Jl. Halim Perdanakusuma, RT.4/RW.5, Kb. Pala, Makasar, Kota Jakarta Timur, Daerah \\ Khusus Ibukota Jakarta, 13650, Indonesia Indonesia \\ ${ }^{2}$ Departemen Ilmu Keluarga dan Konsumen, Fakultas Ekologi Manusia, Institut Pertanian Bogor,
} Bogor 16680, Indonesia

")E-mail: herien_puspitawati@email.com

\begin{abstract}
Abstrak
Perkembangan arus globalisasi yang begitu cepat menyebabkan remaja mengalami berbagai tantangan kehidupan. Penelitian ini bertujuan menganalisis pengaruh dari karakteristik remaja dan keluarga, pengetahuan remaja tentang NAPZA (narkotika, psikotropika, dan zat adiktif), pengetahuan remaja tentang HIV, dan pengetahuan orang tua tentang pembangunan keluarga terhadap Perilaku NAPZA. Metode penelitian ini menggunakan data sekunder Survei Indikator Kinerja Program KKBPK RPJMN 2017 yang dirancang untuk menghasilkan estimasi parameter pada level provinsi dan nasional. Unit analisis adalah remaja usia 15-24 tahun yang belum menikah di seluruh Indonesia. Analisis dalam studi ini dilakukan secara deskriptif dan inferensial menggunakan regresi logistik. Secara garis besar ditemukan bahwa remaja yang rentan terhadap perilaku NAPZA adalah remaja yang tinggal di perkotaan, berusia 20-24 tahun, jenis kelamin laki-laki, berpendidikan dasar, indeks pengetahuan NAPZA menengah, dan indeks pengetahuan HIV menengah. Lebih lanjut, remaja yang rentan terhadap perilaku NAPZA adalah remaja yang berasal dari keluarga dengan umur kepala keluarga kurang dari 40 tahun, tipe keluarga tidak utuh/tunggal, jenis kelamin kepala keluarga perempuan, tingkat pendidikan kepala keluarga menengah-tinggi, keluarga dengan kuintil kekayaan terbawah, dan indeks pengetahuan orang tua pada program pembangunan keluarga yang tinggi.
\end{abstract}

Keywords:pembangunan keluarga, pengetahuan HIV, pengetahuan NAPZA, perilaku NAPZA, remaja

\section{The Influence of Adolescent's Knowledge of Drug and HIV and Parent's Knowledge of Family Development Program on Adolescent's Drug Using Behavior}

\begin{abstract}
The rapid increasing flow of globalization causes young people (including adolescent) experience various challenges in life. The present research proposes the role of demographic factors of young people and their family, young people's knowledge on drug abuse and HIV, and family's knowledge about family development program in drug using among young people. This study used secondary analysis of the 2017 Survey of Population, Family Planning and Family Development Program Performance, National Medium Term Development Plan Year 2017 (KKBPK RPJMN 2017) which was designed to produce parameter in Provincial and National levels. The unit of analysis was young people aged 15-24 years who have never been married in Indonesia. Logistic regression was applied to analyze the inferential statistics. Results indicate that the risk factors of young people which make them more likely to use drug are living in urban area, between the ages of 20-24 years, male, having low education level, having moderate drug abuse and HIV knowledge indexes. The family contexts examining the risk factors are family whose head was under 40 years of age, single-parent family, family whose head was female, family with moderate to high educational level, low level of family's wealth, and high family development program index.
\end{abstract}

Keywords: drug abuse, drug abuse knowledge, family development program, HIV knowledge, young people

\section{PENDAHULUAN}

Keluarga merupakan sekumpulan orang yang memiliki ikatan perkawinan, kelahiran, dan adopsi, dalam perkembangannya dibagi ke dalam delapan tahapan, salah satunya adalah keluarga dengan anak remaja (Duvall \& Miller, 1985). Remaja merupakan generasi penerus bangsa yang harus dipersiapkan dengan maksimal. Tahapan keluarga dengan anak remaja menjadi salah satu tahapan kritis. Beberapa tahapan kritis di antaranya peran 
orang tua terhadap kehidupan sosial anak semakin berkurang, anak tidak tertarik untuk bertanya pendapat orang tua, dan cenderung menyimpan rahasia (Peter, 2015). Pada tahapan ini keluarga harus melakukan perlindungan dan pengasuhan anak yang sesuai dengan tahapan remaja karena remaja berada dalam masa transisi baik secara fisik maupun sosial-psikologi. Usia anak remaja adalah 10-24 tahun melihat faktor kematangan biologis dan faktor perannya dalam lingkungan sosial (Sawyer, Azzopardi, Wickremarathne, \& Patton, 2018). Faktor kematangan biologis dalam hal ini ditandai dengan semakin cepatnya masa pubertas, sementara pada saat yang bersamaan terjadi penundaan peran sosial yang diakibatkan masa sekolah yang semakin lama serta usia pernikahan yang semakin tinggi. Namun pemerintah Indonesia dalam hal ini BKKBN mengategorikan pemuda berusia 15-24 tahun dan belum menikah. Remaja merupakan calon pemimpin bangsa sehingga kualitas sumber daya manusia pada kelompok remaja harus berkualitas, yang dapat ditunjukkan dari fisik dan psikososial yang baik, namun Lyold (2015) menyebutkan bahwa masa remaja merupakan masa yang penuh tantangan dikarenakan masa transisi dari anak menuju dewasa serta pengaruh arus globalisasi. Arus globalisasi merupakan dua sisi mata pisau yang berlawanan, di satu sisi berdampak pada pembangunan dan peningkatan kualitas hidup, sementara di sisi lainnya dapat menurunkan kualitas hidup remaja. Contohnya adanya premarital sexsual yang diakibatkan meningkatnya masa sekolah dan usia pernikahan, penggunaan rokok dan obat-obatan terlarang, serta hubungan seksual yang tidak aman di kalangan anak muda di kebanyakan negara miskin dan berkembang.

Berdasarkan data Kemenkes (2017) prevalensi penyalahgunaan narkoba di kalangan pelajar dan mahasiswa di Indonesia mengalami penurunan dari 2,9 persen di tahun 2011 menjadi 1,9 persen di tahun 2016. Akan tetapi, survei penyalahgunaan dan peredaran gelap narkoba pada kelompok pelajar dan mahasiswa hanya dilakukan di 18 provinsi di tahun 2016 serta angka 1,9 persen masih harus ditindaklanjuti. Hasil penelitian Nisa dan Afriani (2015) menyatakan bahwa hampir sebagian remaja mendapatkan pengetahuan NAPZA (narkotika, psikotropika, dan zat adiktif) dari berbagai sumber baik media seperti internet, televisi, koran dan majalah, orang tua dan guru serta teman dan hanya variabel komunikasi orang tua remaja dan usia remaja yang memiliki hubungan signifikan dengan tingkat pengetahuan remaja terhadap
NAPZA. Penelitian lain menunjukkan bahwa faktor tempat tinggal juga turut memengaruhi tingkat penyalahgunaan obat di kalangan siswa. Kemungkinan siswa yang tidak tinggal bersama orang tua mempunyai resiko 2,808 kali untuk terjerumus dalam penyalahgunaan obat (Afandi, Chandra, Novitasari, Widjaja, \& Kurniawan, 2009).

Penggunaan narkoba, khususnya penggunaan jarum suntik bersama, erat kaitannya dengan penyebaran kasus HIV/ AIDS. Pada tahun 2016, penyebaran kasus HIV positif (1,9\%) dan AIDS (2,6\%) disebabkan oleh pengguna narkoba suntikan. Dari data tersebut mengindikasikan bahwa kondisi remaja saat ini sangat rentan dengan perilaku penylahagunan narkoba yang dapat mengakibatkan kasus HIV /AIDS. Oktarina, Hanafi, dan Budisuari (2009) menyatakan bahwa masyarakat di wilayah perkotaan cenderung berpengetahuan tentang HIV/AIDS baik 0,4 kali dibandingkan wilayah desa. Masyarakat dengan jenis kelamin lakilaki cenderung berpengetahuan tentang HIV/AIDS baik 1,2 kali dibandingkan yang jenis kelamin perempuan.

Lickona (1991) menyatakan bahwa ada sepuluh tanda-tanda kehancuran suatu bangsa yang meliputi meningkatnya kekerasan di kalangan remaja, penggunaan bahasa dan kata-kata kotor, pengaruh kelompok teman yang kuat dalam tindakan kejahatan, meningkatnya perilaku merusak diri seperti narkoba, seks bebas dan alkohol, semakin kaburnya pedoman moral antara hal-hal yang baik dan buruk, penurunan etos kerja, semakin rendahnya rasa hormat kepada orang tua dan guru, rendahnya rasa tanggung jawab sebagai individu dan sebagai warga negara, semakin membudayanya nilai ketidakjujuran, dan semakin meningkatnya rasa kebencian dan saling curiga. Konsisten dengan perspektif ekologi Bronfenbrenner, Ennet et al., (2008) menemukan bahwa pengaruh keluarga sangat terkait erat dibandingkan dengan pengaruh dari teman sebaya, sekolah dan lingkungan dalam penyalahgunaan alkohol dan obatobatan terlarang oleh remaja.

Pengetahuan remaja tentang NAPZA dan HIV, perilaku NAPZA remaja, dan pengetahuan orang tua tentang program pembangunan keluarga menjadi bagian yang penting untuk dikaji karena masih terjadinya penyebaran kasus HIV/AIDS yang disebabkan oleh penggunaan narkoba. Selain itu, bukti penelitian sebelumnya menegaskan bahwa apabila orang tua tidak berperan dengan baik maka kemungkinan remaja untuk 
menyalahgunakan narkoba lebih besar. Berdasarkan pemaparan tersebut, tujuan penelitian ini adalah untuk menganalisis pengaruh dari karakteristik remaja, karakteristik keluarga, pengetahuan remaja tentang NAPZA, pengetahuan remaja tentang HIV, dan pengetahuan orang tua tentang program pembangunan keluarga terhadap perilaku penggunaan NAPZA pada remaja.

\section{METODE}

Penelitian dilakukan dengan menggunakan data sekunder Survei Indikator Kinerja Program Kependudukan, Keluarga Berencana, dan Pembangunan Keluarga Rencana Pembangunan Jangka Menengah Nasional (KKBPK RPJMN) 2017 yang dirancang untuk menghasilkan estimasi parameter pada level provinsi dan nasional. Survei KKBPK RPJMN 2017 merupakan survei berskala nasional yang dilaksanakan oleh Badan Keluarga Berencana Nasional di 34 Provinsi.

Unit analisis adalah remaja pria dan perempuan usia 15-24 tahun dan belum menikah yang merupakan salah satu di antaranya (anak kandung anak tiri, anak angkat, anak asuh) yang menjadi tanggung jawab keluarga yang bersangkutan serta tinggal bersama selama 6 bulan terakhir. Responden remaja tercatat sebagai anggota keluarga pada rumah tangga terpilih dan memenuhi syarat sebagai remaja terpilih. Pengambilan sampel remaja dimulai dengan menentukan klaster (yaitu sebanyak 1.912 klaster dari $514 \mathrm{kab} /$ kota di 34 provinsi), dengan total sampel sebanyak 66.920 rumah tangga. Penentuan total sampel ditentukan dengan metode Probability Proportionate to Size (PPS) sampling, yaitu ditentukan 35 rumah tangga dari setiap klaster. Kemudian dari 66.920 rumah tangga terpilih, yang berhasil ditemui sebanyak 66.672 rumah tangga. Dari 66.672 rumah tangga terpilih dan berhasil diwawancarai, diambil remaja berusia 15-24 tahun yang belum menikah dari rumah tangga tersebut (diperoleh sebanyak 27.187 remaja yang memenuhi syarat). Tetapi yang berhasil diwawancarai dan menjadi sampel/contoh adalah 23.821 remaja (tidak tertimbang) atau 23.878 remaja dengan sampel tertimbang.

Pengumpulan data dilakukan oleh enumerator yang telah mendapatkan pelatihan dengan metode wawancara dan menggunakan smartphone di setiap klaster terpilih yang tersebar di 34 provinsi. Pengumpulan data diselesaikan sampai mencapai 35 rumah tangga beserta remaja pria serta perempuan umur 15-24 tahun belum menikah pada rumah tangga terpilih.

Variabel-variabel yang digunakan dalam analisis dikelompokkan menjadi variabel tidak bebas dan variabel bebas. Variabel tidak bebas yaitu penggunaan NAPZA sedangkan variabel bebas meliputi wilayah tempat tinggal, usia remaja, jenis kelamin remaja, tingkat pendidikan remaja, kelompok umur kepala keluarga, jenis kelamin kepala keluarga, tingkat pendidikan kepala keluarga, kuintil kekayaan keluarga, tipe keluarga, indeks pengetahuan remaja tentang NAPZA, indeks pengetahuan remaja tentang HIV, indeks pengetahuan orang tua tentang program pembangunan keluarga.

Analisis dalam studi ini dilakukan secara deskriptif dan inferensial. Analisis secara deskriptif dilakukan untuk mengidentifikasi remaja menurut karakteristik remaja dan keluarga. Pada saat melakukan pengolahan data pada variable dibuat scoring data, kemudian hasil scoring tersebut dijumlahkan pada masing-masing variable. Skor total kemudian ditransformasikan ke dalam skor indeks sebagai berikut:

Total skor-skor terendah

Indeks $=$ Skor tertinggi-skor terendah $\times 100$

Setelah mendapatkan skor indeks setiap variable, selanjutnya skor tersebut dikelompokkan menjadi tiga kategori yang ditentukan dengan menggunakan cut off pengkategorian yaitu $<60$ dikategorikan rendah, 60-79 dikategorikan sedang, dan $\geq 80$ dikategorikan tinggi. Analisis dilakukan dengan menggunakan tabulasi silang dan analisis tipologi berdasarkan pengetahuan NAPZA dengan perilaku NAPZA dan pengetahuan orang tua tentang pembangunan keluarga dengan perilaku NAPZA yang dilihat berdasarkan jenis kelamin remaja dan wilayah tempat tinggal remaja. Cut off yang digunakan dalam analisis tipologi ada dua, yaitu kategori rendah-sedang $(<80)$ dan tinggi $(\geq 80)$.

Analisis secara inferensial dilakukan dengan uji statistik chi-square untuk mengetahui hubungan antara masing-masing variabel independen dengan variabel dependen yang dianalisis secara bivariat. Analisis inferensial lainnya menggunakan model regresi logistik yang digunakan untuk melihat hubungan beberapa variabel independen terhadap variabel dependen. 


\section{HASIL}

\section{Karakteristik Remaja}

Usia remaja. Berdasarkan hasil penelitian, total remaja laki-laki dalam studi ini sebanyak 13.238 jiwa $(55,4 \%)$ dan remaja perempuan sebanyak 10.640 jiwa $(44,6 \%)$. Remaja lakilaki maupun remaja perempuan berada pada kategori rentang usia $15-19$ tahun $(64,8 \%)$ dan $(70,4 \%)$ dengan proporsi terbesar pada kategori usia 20-24 (35,2\% perempuan dan $29,6 \%$ laki-laki). Rata-rata usia remaja laki-laki 18,56 tahun dan peremuan 18,20 tahun.

Pendidikan remaja. Berdasarkan tingkat pendidikan, lebih dari separuh remaja laki-laki dan perempuan memiliki tingkat pendidikan menengah-tinggi (SMA/SMK/MA ke atas) dengan masing-masing 65 persen dan 76 persen. Remaja yang tinggal di perkotaan maupun di perdesaan memiliki tingkat pendidikan menengah-tinggi masing-masing dengan proporsi 78 persen dan 64 persen.

\section{Karakeristik Keluarga}

Usia kepala keluarga. Berdasarkan hasil penelitian, $21.195(89,0 \%)$ kepala keluarga berjenis kelamin laki-laki dan $2.683(11,0 \%)$ berjenis kelamin perempuan. Selain itu, hampir separuh kepala keluarga berjenis kelamin lakilaki berada pada rentang usia 40-49 tahun $(47 \%)$ sedangkan kepala keluarga berjenis kelamin perempuan proporsi terbesar berada pada rentang usia 50-59 tahun (41\%). Ratarata usia kepala keluarga berjenis kelamin lakilaki 49,63 tahun dan berjenis kelamin perempuan 49,97 tahun.

Pendidikan kepala keluarga. Kepala keluarga baik yang berjenis kelamin laki-laki maupun perempuan lebih banyak yang memiliki tingkat pendidikan dasar, masingmasing 66 persen dan 72 persen. Sementara kepala keluarga berjenis kelamin laki-laki dengan tingkat pendidikan menengah-tinggi (SMA ke atas) tercatat 34,5 persen dan 28 persen pada kepala keluarga berjenis kelamin perempuan. Angka tersebut menunjukkan bahwa kepala keluarga berjenis kelamin lakilaki relatif memiliki tingkat pendidikan yang lebih baik dibandingkan kepala keluarga perempuan. Selanjutnya, kepala keluarga yang bertempat tinggal di perkotaan memiliki tingkat pendidikan menengah-tinggi (SMA ke atas) sebesar 50,2 persen, dibandingkan dengan kepala keluarga yang bertempat tinggal di wilayah perdesaan yaitu sebesar 21,8 persen.

Tipe keluarga. Berdasarkan hasil penelitian, hampir seluruh kepala keluarga berjenis kelamin laki-laki memiliki keluarga utuh $(97,0 \%)$ sedangkan kepala keluarga dengan jenis kelamin perempuan memiliki keluarga tidak utuh sebesar 81,7 persen. Lebih lanjut, kepala keluarga yang tinggal di perkotaan maupun di perdesaan proporsi terbesarnya adalah memiliki tipe keluarga yang utuh $(87,7 \%$ dan $88,5 \%)$.

Kuintil kekayaan keluarga. Hasil penelitian seperti yang tersaji pada Tabel 1 menunjukkan bahwa lebih dari separuh kepala keluarga yang berjenis kelamin laki-laki maupun perempuan berada pada kelompok kuintil kekayaan menengah $\mathrm{ke}$ atas $(64,0 \%$ dan $57,0 \%$ ). Sementara itu, sepertiga keluarga dengan kepala keluarga berjenis kelamin lakilaki $(35,7 \%)$ dan dua dari lima $(43,4 \%)$ keluarga dengan kepala keluarga berjenis kelamin perempuan masuk dalam kuintil kekayaan menengah bawah hingga terbawah. Tabel 1 juga menunjukkan bahwa empat dari lima kepala keluarga $(83,1 \%)$ yang tinggal di perkotaan masuk dalam kuintil kekayaan keluarga menengah hingga teratas. Kepala keluarga yang tinggal di perdesaan separuhnya $(51,0 \%)$ masuk dalam kuintil kekayaan keluarga menengah ke bawah.

Tabel 1 Distribusi persentase kepala keluarga menurut kuintil kekayaan, jenis kelamin dan wilayahtempat tinggal

\begin{tabular}{|c|c|c|c|c|c|c|c|c|}
\hline \multirow{3}{*}{$\begin{array}{c}\text { Kuintil } \\
\text { kekayaan }\end{array}$} & \multicolumn{4}{|c|}{ Jenis kelamin $\mathrm{KK}$} & \multicolumn{4}{|c|}{ Daerah tempat tinggal } \\
\hline & \multicolumn{2}{|c|}{ Laki-laki } & \multicolumn{2}{|c|}{ Perempuan } & \multicolumn{2}{|c|}{ Perkotaan } & \multicolumn{2}{|c|}{ Perdesaan } \\
\hline & $\mathrm{n}$ & $\%$ & $\mathrm{n}$ & $\%$ & $\mathrm{n}$ & $\%$ & $n$ & $\%$ \\
\hline Terbawah & 3.652 & 17,2 & 580 & 21,6 & 520 & 5,2 & 3.712 & 26,9 \\
\hline $\begin{array}{l}\text { Menengah } \\
\text { bawah }\end{array}$ & 3.921 & 18,5 & 585 & 21,8 & 1.188 & 11,8 & 3.318 & 24,1 \\
\hline Menengah & 4.454 & 21,0 & 594 & 22,1 & 1.935 & 19,2 & 3.112 & 22,6 \\
\hline $\begin{array}{l}\text { Menengah } \\
\text { atas }\end{array}$ & 4.598 & 21,7 & 465 & 17,3 & 2.603 & 25,8 & 2.461 & 17,8 \\
\hline Teratas & 4.571 & 21,6 & 459 & 17,1 & 3.837 & 38,1 & 1.192 & 8,6 \\
\hline Total & 21.195 & 100,0 & 2.683 & 100,0 & 10.084 & 100,0 & 13.794 & 100,0 \\
\hline
\end{tabular}


Tabel 2 Sebaran dan uji beda pengetahuan NAPZA, Pengetahuan HIV, dan Pengetahuan Orang tua tentang Pembangunan Keluarga

\begin{tabular}{|c|c|c|c|c|c|c|c|c|c|}
\hline \multirow{2}{*}{ Kategorisasi } & \multicolumn{2}{|c|}{ Rendah } & \multicolumn{2}{|c|}{ Sedang } & \multicolumn{2}{|c|}{ Tinggi } & \multirow{2}{*}{$\begin{array}{l}\text { Rata- } \\
\text { Rata }\end{array}$} & \multirow[b]{2}{*}{$\mathrm{t}$} & \multirow{2}{*}{$p$-value } \\
\hline & $\mathrm{n}$ & $\%$ & $\mathrm{n}$ & $\%$ & $\mathrm{n}$ & $\%$ & & & \\
\hline \multicolumn{10}{|c|}{ Pengetahuan NAPZA } \\
\hline Laki-laki & 5.455 & 41,2 & 3.733 & 28,2 & 4.051 & 30,6 & 26,03 & \multirow{2}{*}{-4.977} & \multirow{2}{*}{$0,000^{* *}$} \\
\hline Perempuan & 4.117 & 38,7 & 2.984 & 28,0 & 3.539 & 33,3 & 27,17 & & \\
\hline Kota & 3.790 & 37,6 & 3.000 & 29,7 & 3.294 & 32,7 & 27,44 & \multirow[b]{2}{*}{6.807} & \multirow{2}{*}{$0,000^{* *}$} \\
\hline Desa & 5.782 & 41,9 & 3.717 & 26,9 & 4.296 & 31,1 & 25,88 & & \\
\hline \multicolumn{10}{|c|}{ Pengetahuan HIV } \\
\hline Laki-laki & 5.455 & 41,2 & 3.733 & 28,2 & 4.051 & 30,6 & 73,19 & \multirow{2}{*}{-8.615} & \multirow{2}{*}{$0,000^{* *}$} \\
\hline Perempuan & 4.117 & 38,7 & 2.984 & 28,0 & 3.539 & 33,3 & 76,78 & & \\
\hline Kota & 3.790 & 37,6 & 3.000 & 29,7 & 3.294 & 32,7 & 80,83 & \multirow{2}{*}{25.185} & \multirow{2}{*}{$0,000^{* *}$} \\
\hline Desa & 5.782 & 41,9 & 3.717 & 26,9 & 4.296 & 31,1 & 70,38 & & \\
\hline \multicolumn{10}{|c|}{ Pengetahuan Orang tua tentang Pembangunan Keluarga } \\
\hline Laki-laki & 2.958 & 22,3 & 5.781 & 43,7 & 4.500 & 34,0 & 32,62 & \multirow{2}{*}{-2.983} & \multirow{2}{*}{$0,003^{* *}$} \\
\hline Perempuan & 2.174 & 20,4 & 4.705 & 44,2 & 3.762 & 35,4 & 33,64 & & \\
\hline Kota & 1.377 & 13,7 & 4774 & 47,3 & 3.932 & 39,0 & 36,80 & \multirow{2}{*}{18,825} & \multirow{2}{*}{$0,000^{* *}$} \\
\hline Desa & 3.755 & 27,2 & 5711 & 41,4 & 4.329 & 31,4 & 30,35 & & \\
\hline
\end{tabular}

\section{Pengetahuan Remaja tentang NAPZA}

Berdasarkan sebaran pengetahuan remaja tentang NAPZA (Tabel 2), sepertiga remaja perempuan $(33,3 \%)$ dan hampir sepertiga remaja laki-laki $(30,6 \%)$ memiliki pengetahuan tentang NAPZA pada kategori tinggi. Berdasarkan hasil uji beda, pengetahuan tentang NAPZA antara remaja laki-laki dan perempuan berbeda sangat signifikan. Remaja perempuan memiliki pengetahuan lebih tinggi (rata-rata indeks 27,17) dibandingkan remaja laki-laki (rata-rata indeks 26,03). Sementara itu, hasil uji beda total pengetahuan tentang NAPZA berdasarkan wilayah tempat tinggal remaja menunjukkan terdapat perbedaan yang signifikan antara wilayah kota $(27,44)$ dan desa $(25,88)$. Pengetahuan remaja tentang NAPZA di wilayah kota lebih tinggi dibandingkan remaja di wilayah desa. Selain itu, hampir sepertiga remaja di kota $(32,7 \%)$ dan desa $(31,1 \%)$ memiliki pengetahuan NAPZA pada kategori tinggi, namun 37,6 persen remja di wilayah kota dan 41,9 persen di wilayah desa masih masuk pada kategori pengetahuan NAPZA yang masih rendah.

\section{Pengetahuan Remaja tentang HIV}

Berdasarkan sebaran pengetahuan tentang HIV (Tabel 2), hampir separuh remaja laki-laki $(41,2 \%)$ dan perempuan $(38,7 \%)$ memiliki pengetahuan tentang HIV pada kategori rendah. Hasil uji beda menunjukkan pengetahuan HIV antara remaja laki-laki dan perempuan berbeda secara signifikan.
Remaja perempuan memiliki rata-rata indeks pengetahuan $(76,78)$ lebih tinggi dibandingkan remaja laki-laki $(73,19)$. Berdasarkan hasil uji beda pengetahuan tentang HIV secara total berdasarkan wilayah, terdapat perbedaan yang sangat signifikan yang mana remaja di wilayah perkotaaan memiliki pengetahuan $(80,83)$ yang lebih baik dibandingkan remaja di wilayah desa $(70,38)$. Berdasarkan kategorisasi pengetahuan tentang HIV, baik remaja yang tinggal di perkotaan maupun diperdesaan lebih banyak masuk pada kategori rendah, masing-masing 37,6 persen dan 41,9 persen.

\section{Pengetahuan Orang tua tentang Program Pembangunan Keluarga}

Tabel 2 sebaran pengetahuan orang tua tentang pembangunan keluarga, hampir separuh orang tua remaja laki-laki $(43,7 \%)$ dan perempuan $(44,2 \%)$ memiliki pengetahuan tentang pembangunan keluarga pada kategori sedang. Penelitian menemukan adanya perbedaan yang signifikan antara orang tua remaja perempuan $(33,64)$ yang mana pengetahuannya lebih baik dibandingkan orang tua remaja laki-laki $(32,62)$. Selanjutnya, orang tua remaja di wilayah perkotaan $(36,80)$ memiliki pengetahuan lebih baik dibandingkan orang tua remaja di wilayah perdesaan $(30,35)$. Hampir separuh orang tua remaja di wilayah perkotaan $(47,3 \%)$ dan orang tua remaja di wilayah perdesaan $(41,4 \%)$ memiliki pengetahuan tentang program pembangunan keluarga pada kategori sedang. 
Tabel 3 Uji Beda Perilaku NAPZA berdasarkan jenis kelamin dan wilayah

\begin{tabular}{|c|c|c|c|c|c|c|}
\hline \multirow{2}{*}{ Pertanyaan } & \multicolumn{2}{|c|}{ Rata-rata } & \multirow{2}{*}{$p$-value } & \multicolumn{2}{|c|}{ Rata-rata } & \multirow[t]{2}{*}{$p$-value } \\
\hline & Laki-laki & Perempuan & & Kota & Desa & \\
\hline $\begin{array}{l}\text { Pernah mencoba } \\
\text { mengonsumsi NAPZA }\end{array}$ & 0,12 & 0,05 & $0,000^{* *}$ & 0,08 & 0,09 & 0,099 \\
\hline
\end{tabular}

Dua dari lima orang tua remaja di wilayah perkotaan $(39,0 \%)$ dan hampir sepertiga orang tua remaja di wilayah perdesaan $(31,4)$ memiliki pengetahuan tentang program pembangunan keluarga pada kategori tinggi.

\section{Perilaku NAPZA Remaja}

Hasil penelitian menunjukkan bahwa hampir seluruh $(91,5 \%)$ remaja tidak pernah mencoba mengonsumsi NAPZA. Hanya 8,5 persen remaja yang mengaku pernah mencoba NAPZA. Hasil uji beda menunjukkan bahwa terdapat perbedaan yang sangat signifikan $(\alpha=0,000)$ antara remaja laki-laki dengan remaja perempuan, remaja laki-laki $(0,12)$ lebih banyak yang pernah mencoba mengonsumsi NAPZA dibandingkan remaja perempuan $(0,05)$. Berdasarkan wilayah, remaja di wilayah perdesaan $(0,09)$ lebih banyak yang pernah mengonsumsi NAPZA dibandingkan remaja di wilayah perkotaan $(0,08)$, namun tidak berbeda signifikan .

\section{Tipologi Pengetahuan NAPZA dan HIV dengan Perilaku NAPZA}

Berdasarkan Gambar 1, sebanyak 54,8 persen remaja laki-laki dan 62,4 persen remaja perempuan masuk pada tipe 3 yaitu memiliki pengetahuan NAPZA tinggi dan perilaku NAPZA yang rendah. Namun masih terdapat 7,6 persen remaja laki-laki dan 3,5 persen remaja perempuan yang masuk pada kategori tipe 2 yaitu pengetahuan NAPZA tinggi namun perilaku NAPZA nya juga tinggi.

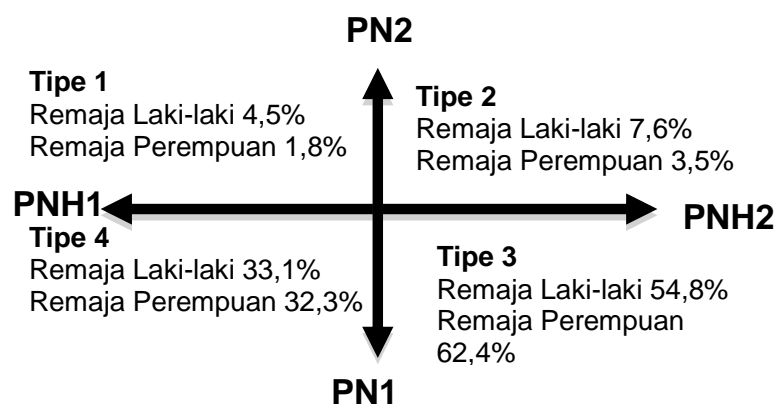

Gambar 1 Tipologi Pengetahuan NAPZA dan HIV dengan Perilaku NAPZA Berdasarkan Jenis Kelamin

Keterangan:

$\mathrm{PNH} 2=$ Pengetahuan NAPZA sedang-tinggi; $\mathrm{PNH} 1=$ Pengetahuan NAPZA rendah; PN2= Perilaku NAPZA sedang- tinggi; PN1 = Perilaku NAPZA rendah
Sementara itu, berdasarkan Gambar 2, tipe tiga yaitu pengetahuan orang tua tentang program pembangunan keluarga yang tinggi dengan perilaku NAPZA yang rendah memiliki persentase terbanyak yaitu 69,6 persen pada remaja laki-laki dan 76,6 persen pada remaja perempuan. Selain itu, terdapat 9,9 persen keluarga remaja laki-laki dan 4,7 persen keluarga remaja peremuan yang memiliki pengetahuan orang tua tentang program pembangunan keluarga yang tinggi dan perilaku remaja dalam penggunaan NAPZA yang tinggi.

\section{Tipologi Pengetahuan Orang tua tentang Pembangunan Keluarga dengan Perilaku NAPZA}

Berdasarkan Gambar 3, sebanyak 61,0 persen remaja di wilayah kota dan 55,8 persen remaja di wilayah desa masuk pada tipe 3 yaitu memiliki pengetahuan remaja tentang NAPZA kategori tinggi dan perilaku remaja dalam menggunakan NAPZA yang tinggi. Namun, masih terdapat masing-masing 5,8 persen di wilayah kota dan di wilayah desa yang masuk pada kategori tipe 2 yaitu pengetahuan NAPZA tinggi namun perilaku NAPZA nya tinggi.

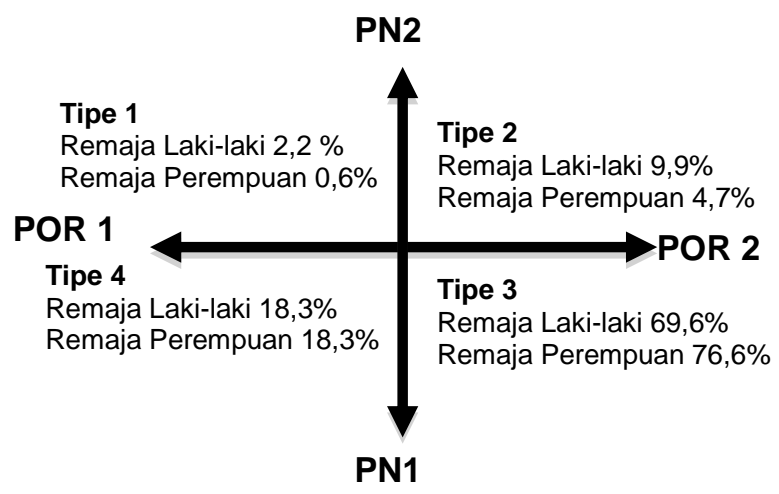
Gambar 2 Tipologi Pengetahuan Orang tuatentang Pembangunan Keluarga dengan Perilaku NAPZA Berdasarkan Jenis Kelamin

Keterangan

POR2= Pengetahuan Orang tua tentang Pembangunan Keluarga sedang-tinggi

POR1= Pengetahuan Orang tua tentang Pembangunan Keluargarendah

PN2= Perilaku NAPZA sedang-tinggi

PN1 = Perilaku NAPZA rendah 


\section{PN 2}

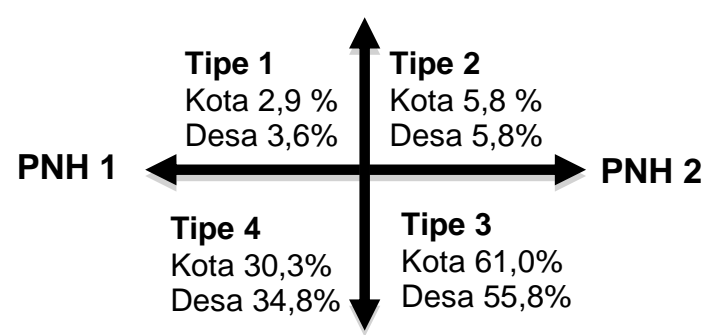

PN 1

Gambar 3 Tipologi Pengetahuan Pengetahuan Orang tua tentang Pembangunan Keluarga dengan Perilaku NAPZA Berdasarkan Wilayah

Keterangan

$\mathrm{PNH} 2=$ Pengetahuan NAPZA sedang-tinggi

$\mathrm{PNH} 1=$ Pengetahuan NAPZA rendah

$P N 2=$ Perilaku NAPZA sedang-tinggi

$\mathrm{PN} 1=$ Perilaku NAPZA rendah

Gambar 4 menunjukkan bahwa tipe tiga yaitu pengetahuan orang tua tentang program pembangunan keluarga yang tinggi dengan perilaku remaja dalam menggunakan NAPZA yang tinggi memiliki persentase terbanyak yaitu 79,6 persen pada keluarga remaja di wilayah perkotaan dan 66,8 persen pada keluarga remaja di wilayah perdesaan. Namun masih terdapat 7,8 persen keluarga remaja di wilayah perkotaan dan 7,4 persen keluarga remaja di wilayah perdesaan yang memiliki pengetahuan orang tua tentang program pembangunan keluarga yang tinggi dan perilaku remaja dalam menggunakan NAPZA yang tinggi.

\section{PN 2}

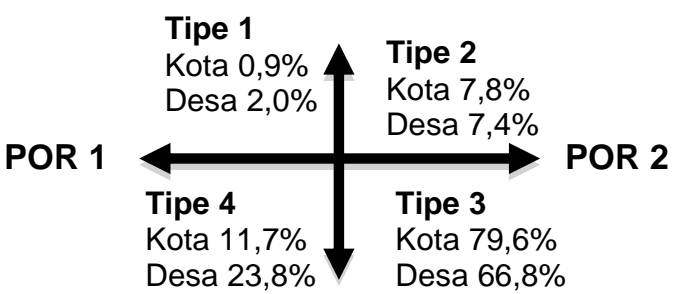

PN1

Gambar 4 Tipologi

Pengetahuan

Pengetahuan Orang tua tentang

Pembangunan Keluarga dengan

Perilaku NAPZA Berdasarkan

Wilayah

Keterangan

POR2 $=$ Pengetahuan Orang tua tentang Remaja sedangtinggi

POR1 $=$ Pengetahuan Orang tua tentang Remaja rendah

$\mathrm{PN} 2=$ Perilaku NAPZA sedang-tinggi; PN1= Perilaku NAPZA rendah

\section{Uji Kesesuaian Model Regresi Logistik}

Nilai -2 log likelihood digunakan untuk uji keseluruhan model (overall model fit test) dalam menilai model yang telah dihipotesiskarPNHthzil uji menemukan terjadi penurunan -2 log likelihood setelah dimasukkan variabel independen dari $22.124,156$ menjadi $17.547,436$ sehingga model regresi logistik yang digunakan merupakan yang model fit. Uji estimasi parameter secara serentak pada analisis regresi logistik biner menghasilkan nilai Chisquare sebesar $19.570,115$ dengan nilai signifikansi 0,00 dibawah nilai $p$-value $(0,05)$. Artinya, minimal ada satu variabel independen yang signifikan memengaruhi variabel dependen. Selanjutnya, pengujian koefisien determinasi pada regresi logistik menggunakan pendekatan dengan nilai Nagelkerke $R$-Square sebesar 0,638 , yang artinya variabilitas variabel dependen yang dapat dijelaskan oleh variabilitas variabel independen sebesar 63,8 persen. Hasil classification table menunjukkan secara keseluruhan ketepatan model sebesar 86,5 persen.

Pengaruh karakteristik remaja, orang tua, wilayah tempat tinggal, pengetahuan tentang NAPZA, pengetahuan tentang HIV, dan pengetahuan orang tua tentang pembangunan keluarga terhadap perilaku NAPZA

Hasil penelitian selanjutnya menunjukkan bahwa hasil analisis regresi biner logistik menjelaskan bahwa semua variabel independen yaitu wilayah tempat tinggal, usia remaja, jenis kelamin remaja. tingkat pendidikan remaja, kelompok umur kepala keluarga, jenis kelamin kepala keluarga, tingkat pendidikan kepala keluarga, kuintil kekayaan, tipe keluarga, indeks pengetahuan NAPZA, indeks pengetahuan HIV, indeks pengetahuan pembangunan keluarga secara signifikan berpengaruh terhadap perilaku penggunaan NAPZA pada remaja (Tabel 4). Wilayah tempat tinggal berpengaruh positif terhadap probabilitas menggunakan NAPZA. Probabilitas remaja yang bertempat tinggal di perkotaan 1,18 lebih tinggi menggunakan NAPZA dibandingkan remaja yang ada di perdesaan. Hasil uji beda pada Tabel 3 sebelumnya, menyatakan bahwa remaja yang tinggal di perdesaan sedikit lebih banyak yang mengkonsumsi NAPZA dari remaja yang tinggal di perkotaan, namun hasil ini tidak signifikan. 
Tabel 4 Pengaruh karakteristik remaja, orang tua, wilayah tempat tinggal, pengetahuan tentang NAPZA, pengetahuan tentang HIV, dan pengetahuan orang tua tentang pembangunankeluarga terhadap perilaku NAPZA

\begin{tabular}{|c|c|c|c|}
\hline Variabel & Koefisien $\beta$ & Sig. & $\operatorname{Exp}(\beta)$ \\
\hline \multicolumn{4}{|l|}{ Daerah Tempat Tinggal } \\
\hline Perkotaan & 0,17 & $0,00^{*}$ & 1,18 \\
\hline Perdesaan** & - & & 1,00 \\
\hline \multicolumn{4}{|l|}{ Usia Remaja } \\
\hline $15-19^{\star \star}$ & - & & 1,00 \\
\hline $20-24$ & 0,99 & $0,00^{*}$ & 2,68 \\
\hline \multicolumn{4}{|l|}{ Jenis Kelamin Remaja } \\
\hline Perempuan** & - & & 1,00 \\
\hline Laki-laki & 0,28 & $0,00^{*}$ & 1,32 \\
\hline \multicolumn{4}{|l|}{ Tingkat pendidikan Remaja } \\
\hline Pendidikan Dasar & 1,03 & $0,00^{*}$ & 2,80 \\
\hline Pendidikan Menengah-tinggi** & - & & 1,00 \\
\hline \multicolumn{4}{|l|}{ Kelompok Umur Kepala Keluarga } \\
\hline$<40$ tahun & 0,65 & $0,00^{*}$ & 1,92 \\
\hline 40-49 tahun & $-1,15$ & $0,00^{*}$ & 0,32 \\
\hline 50-59 tahun & $-1,17$ & $0,00^{*}$ & 0,31 \\
\hline$>60$ tahun $^{\star *}$ & - & & 1,00 \\
\hline \multicolumn{4}{|l|}{ Jenis Kelamin Kepala Keluarga } \\
\hline Laki-laki** & - & & 1,00 \\
\hline Perempuan & 1,26 & $0,00^{*}$ & 3,52 \\
\hline \multicolumn{4}{|l|}{ Tingkat pendidikan Kepala Keluarga } \\
\hline Pendidikan Dasar & $-0,96$ & $0,00^{*}$ & 0,38 \\
\hline Pendidikan Menengah-Tinggi** & - & & 1,00 \\
\hline \multicolumn{4}{|l|}{ Kuintil Kekayaan } \\
\hline Terbawah & 0,36 & $0,00^{*}$ & 1,43 \\
\hline Menengah bawah & 0,23 & $0,00^{*}$ & 1,26 \\
\hline Menengah & 0,11 & 0,07 & 1,12 \\
\hline Menegah Atas & 0,07 & 0,24 & 1,08 \\
\hline Teratas $^{* \star}$ & - & & 1,00 \\
\hline \multicolumn{4}{|l|}{ Tipe Keluarga } \\
\hline Keluarga Utuh** & - & & 1,00 \\
\hline Lainnya/Tidak Utuh & 0,92 & $0,00^{*}$ & 2,52 \\
\hline \multicolumn{4}{|l|}{ Indeks Pengetahuan NAPZA } \\
\hline Rendah & $-0,49$ & $0,00^{*}$ & 0,60 \\
\hline Menengah & 0,13 & $0,00^{*}$ & 1,14 \\
\hline Tinggi** & - & & 1,00 \\
\hline \multicolumn{4}{|l|}{ Indeks Pengetahuan HIV } \\
\hline Rendah & 0,23 & $0,00^{*}$ & 1,27 \\
\hline Menengah & 0,31 & $0,00^{*}$ & 1,37 \\
\hline 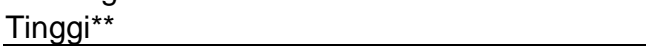 & - & & 1,00 \\
\hline \multicolumn{4}{|l|}{ Indeks Pengetahuan Pembangunan Keluarga } \\
\hline Rendah & 0,02 & 0,61 & 1,03 \\
\hline Menengah & $-0,21$ & $0,00^{*}$ & 0,80 \\
\hline Tinggi** & - & & 1,00 \\
\hline
\end{tabular}

Keterangan:

* = signifikan pada $\alpha=0,01$

** $=$ kategori referensi

Setelah diuji lebih lanjut dengan analisis regresi biner logitik yang melibatkan variabel independen lainnya di temukan bahwa remaja di perkotaan secara signifikan lebih banyak mengkonsumsi NAPZA. Usia remaja juga berpengaruh positif terhadap probabilitas menggunakan NAPZA. Remaja yang masuk kategori usia 20-24 memiliki kecenderungan menggunakan NAPZA 2,68 kali dibandingkan remaja yang berusia 15-19 tahun. Remaja lakilaki 1,32 kali lebih cenderung untuk menggunakan NAPZA dibandingkan dengan remaja perempuan dan remaja dengan tingkat pendidikan dasar juga cenderung menggunakan NAPZA sebesar 2,8 kali dibandingkan dengan tingkat pendidikan tinggi.

Hasil lain juga menunjukkan bahwa remaja yang berasal dari keluarga dengan kepala keluarga masuk dalam kategori usia $<40$ tahun lebih cenderung menggunakan NAPZA daripada remaja yang memiliki kepala 
keluarga usia $>60$ tahun. Sementara remaja yang memiliki kepala keluarga usia 40-49 tahun serta 50-59 tahun memiliki probabilitas masing-masing 0,3 kali kurang cenderung menggunakan NAPZA. Jenis kelamin kepala keluarga berpengaruh positif terhadap penggunaan NAPZA. Remaja yang yang berasal dari keluarga dengan kepala keluarga berjenis kelamin perempuan 3,5 kali lebih tinggi menggunakan NAPZA dibandingkan dengan remaja yang berasal dari keluarga dengan kepala keluarga berjenis kelamin lakilaki. Sementara, remaja yang memiliki kepala keluarga berpendidikan rendah 0,38 kali kurang cenderung untuk menggunakan NAPZA dibandingkan yang berpendidikan tinggi.

Kuintil kekayaan dan tipe keluarga juga berpengaruh positif terhadap penggunaan NAPZA. Remaja yang berasal dari keluarga dengan kuintil kekayaan terbawah memiiki peluang 1,43 kali cenderung untuk menggunakan NAPZA. Begitu juga remaja yang berasal dari keluarga dengan kuintil kekayaan menengah bawah lebih cenderung menggunakan NAPZA sebesar 1,26 kali dibandingkan dengan remaja yang berasal dari kuintil teratas. Lebih lanjut, remaja yang berasal dari keluarga lainnya/tidak utuh memiliki probabilitas 2,52 kali menggunakan NAPZA dari remaja dengan keluarga utuh. Hasil ini menunjukkan rentannya remaja menngunakan NAPZA jika berasal dari keluarga yang tidak utuh.

Selain itu, remaja yang memiliki indeks pengetahuan NAPZA yang rendah memiliki probabilitas 0.6 kali kurang cenderung menggunakan NAPZA namun remaja yang memiliki indeks pengetahuan NAPZA yang sedang 1,14 kali lebih cenderung untuk menggunakan NAPZA. Sementara remaja dengan pengetahuan HIV yang rendah dan sedang lebih cenderung untuk menggunakan NAPZA dengan probabilitas 1,27 kali dan 1,37 kali dari remaja yang memiliki indeks pengetahuan HIV tang tinggi. Selanjutnya, remaja dengan orang tua yang memiliki pengetahuan tentang program pembangunan keluarga sedang lebih kurang cenderung menggunakan NAPZA 0,8 kali sebesar 1,03 kali dari remaja dengan orang tua dengan indeks pengetahuan tentang program pembangunan keluarga yang tinggi.

\section{PEMBAHASAN}

Pandangan teori ekologi keluarga dapat dikaitkan dengan proses sosialisasi anak-anak dalam membentuk kualitas sumber daya manusia. Bronfenbrenner menyajikan model pandangan dari segi ekologi dalam mengerti proses sosialisasi anak-anak. Model tersebut menempatkan posisi anak pada pusat di dalam model yang secara langsung dapat berinteraksi dengan lingkungan mikrosistem (keluarga, sekolah, teman sebaya, dan tetangga), lingkungan mesosistem, lingkungan exosystem dan lingkungan makrosistem (Klein \& White, 1996).

Hasil penelitian menunjukkan bahwa remaja yang rentan terhadap perilaku NAPZA adalah remaja yang tinggal di perkotaan. Kondisi ini kemungkinan dapat disebabkan karena orang tua remaja yang tinggal di perkotaan memiliki penghasilan yang lebih tinggi sehingga peluang remaja untuk mendapatkan narkoba lebih besar. Selain itu, kemudahan dalam penyebaran distribusi obat-obatan terlarang di suatu wilayah juga menyebabkan tingginya penggunaan NAPZA. Hasil penelitian ini sejalan dengan penelitian yang dilakukan oleh Tutussaus dan Balic (2016) yang menyatakan bahwa penggunaan NAPZA oleh remaja lebih banyak ditemukan di daerah perkotaan dibandingkan di daerah perdesaan. Hasil ini bertentangan dengan preposisi yang diajukan oleh Keyes, Cerda, Brady, Havens, \& Galea, (2014) mengatakan bahwa remaja pengguna NAPZA lebih banyak ditemukan di perdesaan.

Selain itu, remaja yang rentan terhadap perilaku NAPZA berasal dari keluarga dengan umur kepala keluarga kurang dari 40 tahun. Remaja yang menjadi responden pada survei RPJMN 2017 adalah mereka yang belum menikah dan berusia 15-24 tahun. Artinya, jika remaja yang menjadi responden adalah anak pertama maka kepala keluarga dari remaja tersebut menikah pertama kali pada rentang usia antara 15-24 tahun. Hal tersebut mengindikasikan bahwa remaja yang cenderung menggunakan NAPZA berasal dari keluarga yang menikah muda. Pernikahan yang terjadi pada usia yang masih sangat muda akan rentan pada permasalahan sosial dan mental, termasuk kekerasan dalam rumah tangga dan penggunaan NAPZA (Hovdestad, Shields, Williams, \& Tonmyr, 2015). Bahkan anak-anak dari pasangan usia muda juga rentan untuk tidak mendapatkan kasih sayang dari orang tua mereka, beresiko pada penggunaan minuman keras/alkohol bahkan melakukan hubungan seksual di usia yang masih sangat muda (Cavazos et al., 2010).

Remaja berusia 20-24 tahun, berjenis kelamin laki-laki,dan berpendidikan dasar juga rentan 
terhadap perilaku penggunaan NAPZA. Hal ini dapat disebabkan karena remaja dengan rentang usia 20-24 tahun sudah memiliki otonomi atau kebebasan terhadap dirinya sendiri dibandingkan remaja dengan kelompok usia di bawahnya. Otonomi tersebut memungkinkan remaja lebih cepat terpengaruh dengan NAPZA. Namun, terkait hasil tentang rentang usia remaja yang menggunakan NAPZA bertentangan dengan penelitian sebelumnya. Kondisi penelitian memperlihatkan bahwa semakin tinggi usia remaja maka kecenderungan menggunakan NAPZA akan semakin kecil (Tutussaus \& Balic, 2016) dan hasil penelitian lain juga menyatakan pelajar yang menyalahgunakan NAPZA sebagian besar berada pada usia remaja awal (Nur'artavia, 2017). Akan tetapi, hasil penelitian sejalan dengan penelitian pada (Kabir, Goh, Kamal, \& Khan, 2013) yang menemukan bahwa remaja pada rentang usia 20-24 tahun lebih cenderung menggunakan NAPZA dibandingkan pada rentang usia 15-19 tahun serta remaja yang berpendidikan rendah cenderung menggunakan NAPZA dibandingkan remaja yang berpendidikan tinggi. Secara umum, pendidikan terkait erat dengan pengetahuan yang dimiliki seseorang. Hasil penelitian juga sejalan dengan penelitian yang menyatakan bahwa secara keseluruhan laki-laki lebih bermasalah dalam penyalahgunaan obat dibandingkan perempuan (Afandi, Chandra, Novitasari, Widjaja, \& Kurniawan, 2009; Turner, Turner, Yang, Luo 2013; Nur'atavia, 2017). Berdasarkan analisis tipologi menunjukkan bahwa lebih dari separuh remaja pada survei RPJMN 2017 memiliki pengetahuan yang tinggi akan resiko NAPZA dan kecil kemungkinan menggunakan NAPZA.

Remaja dengan tipe keluarga tidak utuh/tunggal dan berasal dari keluarga dengan kepala keluarga berjenis kelamin perempuan lebih rentan dengan perilaku NAPZA. Penelitian ini sesuai dengan beberapa penelitian sebelumnya yang menemukan bahwa remaja yang tinggal pada keluarga tidak utuh/tunggal lebih beresiko menggunakan NAPZA (Amoateng \& Bahr, 1986; Hoffmann \& Johnson, 1998; Hoffman, 2002). Namun, jika dilihat berdasarkan jenis kelamin kepala keluarga dari remaja yang rentan dengan perilaku NAPZA, maka hasil penelitian ini tidak sejalan dengan penelitian sebelumnya yang menemukan bahwa remaja yang tinggal pada keluarga yang hanya memiliki ayah memiliki resiko lebih tinggi akan menyalahgunakan NAPZA dibandingkan remaja yang tinggal hanya dengan ibunya
(Hoffmann \& Johnson, 1998; Hoffman, 2002; Hemovich \& Crano, 2009).

Remaja yang tinggal pada keluarga dengan kuintil kekayaan terbawah cenderung beresiko menggunakan NAPZA. Hal ini sejalan dengan (Laoniramau, Laosee, Somrongthong, Sunanta, \& Sitthiamorns, 2005; Keyes, Cerda, Brady, Havens, \& Galea, 2014) yang menemukan bahwa tekanan ekonomi dapat membuat kecenderungan remaja menggunakan NAPZA lebih tinggi. Akan tetapi, hal ini berlawanan dengan (Humensky, 2010) yang menemukan bahwa remaja yang datang dari keluarga dengan status ekonomi yang tinggi cenderung menggunakan NAPZA dikarenakan kemudahan untuk membeli barang tersebut.

Remaja yang tinggal dengan kepala keluarga memiliki tingkat pendidikan menengah-tinggi cenderung menggunakan NAPZA. Hal ini dapat disebabkan semakin tingginya perolehan pendapatan kepala keluarga yang memiliki pendidikan menengah-tinggi memungkinkan anaknya lebih mudah untuk mendapatkan akses NAPZA. Selain itu pendidikan orang tua yang tinggi memungkinkan terjadinya mobilitas bekerja orang tua yang tinggi sehingga tingkat pengawasan pada anak dapat berkurang Sejalan dengan penelitian (Humensky, 2010) juga menemukan bahwa pemuda yang masuk dalam kategori dewasa awal (lebih dari 20 tahun) dan datang dari keluarga dengan orang tua berpendidikan tinggi cenderung menggunakan NAPZA. Sementara (Amoateng \& Bahr, 1986) menemukan bahwa tidak ada hubungan antara tingkat pendidikan orang tua dengan penggunaan NAPZA pada remaja.

Remaja dengan indeks pengetahuan NAPZA menengah cenderung menggunakan NAPZA dibandingkan remaja dengan indeks pengetahuan tinggi. Akan tetapi, hasil ini menjadi tidak konsisten ketika ditemukan bahwa remaja dengan indeks pengetahuan yang rendah cenderung untuk tidak menggunakan NAPZA. Demikian pula dengan indeks pengetahuan HIV/AIDS dan kecenderungan remaja untuk menggunakan NAPZA. Remaja dengan indeks pengetahuan HIV/AIDS menengah cenderung lebih menggunakan NAPZA dibandingkan remaja yang memiliki indeks pengetahuan HIV/ AIDS rendah dan tinggi. Penelitian yang dilakukan (Malik et al., 2012) menemukan bahwa meski kesadaran akan resiko penggunaan NAPZA lebih tinggi pada remaja yang tidak menggunakan NAPZA, akan tetapi masih 
banyak ditemukan remaja yang terus menggunakan NAPZA meskipun telah mengetahui bahaya NAPZA. Hal ini juga diperkuat oleh hasil penelitian (Poole \& Evans, 1987) bahwa rasa takut akan resiko penggunaan NAPZA hanya berlaku pada remaja yang tidak menggunakan NAPZA, sedangkan remaja yang telah menggunakan NAPZA kecil kemungkinan menggunakan pengetahuannya untuk menyadari bahaya NAPZA.

Secara umum remaja lebih membutuhkan pengetahuan life skill daripada pengetahuan tentang NAPZA. Laoniramau, Laosee, Somrongthong, Sunanta, \& Sitthiamorns, (2005); Poole dan Evans (1987) menemukan bahwa pengetahuan life skill dibandingkan pengetahuan akan bahaya NAPZA menjadi faktor yang paling mampu mencegah remaja menggunakan NAPZA. Pengetahuan life-skill berfungsi untuk meningkatkan keyakinan dan kemampuan untuk mengendalikan konteks hidupnya sendiri. Sebagaimana perspektif Erik Erikson mengenai tahapan perkembangan psikososial, yang mana remaja merupakan masa terjadinya konflik pencarian identitas dan peran (identity vs role confusion). Remaja butuh untuk mendefinisikan dirinya sendiri dan menjadi independen (Curtis, 2015). Fungsi keluarga disini dilihat dari pola komunikasi yang terbuka dan dua arah (keterlibatan peran orang tua dalam keseharian remaja), pemberian hadiah/reward kepada remaja atas perbuatannya yang positif. Ketika keluarga tidak berfungsi dengan baik maka remaja akan mengalami kebingungan peran (role confusion) dan mengalami permasalahan. Sebaliknya jika fungsi keluarga berjalan dengan baik maka kebingungan peran dan permasalahan remaja dapat dicegah (Schwartz \& Pantin, 2005).

Remaja dari keluarga yang memiliki orang tua dengan indeks pengetahuan tentang program pembangunan keluarga tinggi cenderung menggunakan NAPZA dibandingkan remaja yang berasal dari keluarga dengan indeks pengetahuan orang tua kategori menengah. Ennet et al. (2008) dalam temuannya dengan perspektif ekologi Bronfenbrenner menegaskan bahwa hanya fungsi pengawasan dan kontrol dari orang tua yang dapat menjelaskan dampak pada penyalahgunaan alkohol dan NAPZA pada remaja. Walaupun, pengetahuan orang tua tetap harus ditingkatkan sebagaimana temuan Ollalla, Fraguela, Antonio, \& Jorge, (2017) yang menyatakan bahwa dukungan orang tua hanya dapat efektif dalam mengurangi tingkat kenakalan remaja (termasuk di antaranya adalah penyalahgunaan NAPZA) dengan meningkatkan pengetahuan orang tua. Selain fungsi pengawasan dan kontrol orang tua, pola komunikasi dan pengasuhan juga perlu disesuaikan dengan tahapan perkembangan remaja. Penelitian sebelumnya menemukan bahwa keluarga konsensual yang dicirikan dengan komunikasi terbuka dan dua arah yang kemudian dikombinasikan dengan pemberian aturan yang tegas dan penghargaan bagi anaknya yang tidak menggunakan NAPZA sangat berpengaruh dalam meminimalisir penggunaan NAPZA pada remaja tahap akhir (Marceau, Abar, \& Jackson, 2015; Ratnasari, 2015; Day, 2016).

Penelitian ini telah membuktikan kebenaran grand theory struktural fungsional bahwasanya keluarga yang mempunyai struktur utuh lebih baik dibandingkan dengan keluarga yang tidak utuh. Penelitian ini juga membuktikan teori Bronfenbrener bahwa perilaku remaja dipengaruhi oleh keluarga dan lingkungannya. Keterbatasan penelitian ini adaah masih banyak terdapat faktor lain yang belum dapat dianalisa tetapi ada kemungkinan berpengaruh pada penggunaan NAPZA di kalangan remaja. Misalnya, pengetahuan life-skill pada remaja, pola pengasuhan orang tua dan pola komunikasi orang tua yang mungkin berpengaruh sangat besar pada penggunaan NAPZA di kalangan remaja. Ada dinamika fungsi keluarga (terutama pada fungsi pengawasan dan kontrol orang tua) yang mungkin memiliki pengaruh pada perilaku remaja dan belum terlihat pada survei ini.

\section{SIMPULAN DAN SARAN}

Rata-rata usia remaja laki-laki 18,56 tahun dan perempuan 18,20 tahun. Sementara itu, lebih dari separuh remaja laki-laki dan perempuan memiliki tingkat pendidikan menengah-tinggi (SMA/SMK/MA ke atas). Hasil lain juga menunjukan bahwa hampir separuh kepala keluarga berjenis kelamin laki-laki dan berada pada rentang usia 40-49 tahun. Adapun kepala keluarga berjenis kelamin perempuanberada pada rentang usia 50-59 tahun. Kepala keluarga berjenis kelamin laki-laki relatif memiliki tingkat pendidikan yang lebih baik dibandingkan kepala keluarga perempuan. Selanjutnya, hampir seluruh kepala keluarga berjenis kelamin laki-laki memiliki keluarga utuh, sedangkan kepala keluarga dengan jenis kelamin perempuan empat per lima memiliki keluarga tidak utuh. Sementara itu, lebih dariseparuh kepala keluarga yang berjenis kelamin laki-laki maupun perempuan berada 
pada kelompok kuintil kekayaan menengah ke atas.

Hasil studi ini menunjukkan bahwa sepertiga remaja perempuan dan hampir sepertiga remaja laki-laki memiliki pengetahuan tentang NAPZA pada kategori tinggi. Selain itu, hampir separuh remaja laki-laki dan perempuan memiliki pengetahuan tentang HIV pada kategori rendah. Remaja perempuan memiliki rata-rata pengetahuan NAPZA dan HIV/AIDS lebih tinggi dibandingkan remaja laki-laki. Pengetahuan remaja tentang NAPZA dan HIV/AIDS di wilayah kota lebih tinggi dibandingkan remaja di wilayah desa. Berdasarkan pengetahuan orang tua tentang program pembangunan keluarga, orang tua remaja perempuan memiliki pengetahuan yang lebih baik dibandingkan orang tua remaja lakilaki sedangkan orang tua remaja di wilayah perkotaan memiliki pengetahuan lebih baik dibandingkan orang tua remaja di wilayah perdesaan. Berdasarkan tipologi pengetahuan NAPZA dan HIV dengan perilaku NAPZA dan tipologi pengetahuan orang tua tentang program pembangunan keluarga dengan perilaku NAPZA, mayoritas remaja masuk pada kuadran terbaik yaitu kuadaran dengan tingkat pengetahuan tinggi dan perilaku NAPZA yang rendah. Berdasarkan perilaku NAPZA remaja laki-laki lebih banyak yang pernah mencoba mengonsumsi NAPZA dibandingkan remaja perempuan. Secara garis besar ditemukan bahwa remaja yang rentan terhadap perilaku NAPZA adalah remaja yang tinggal di perkotaan, berusia 20-24 tahun, berjenis kelamin laki-laki, dan berpendidikan dasar. Remaja yang rentan terhadap perilaku penggunaan NAPZA adalah remaja yang berasal dari keluarga dengan umur kepala keluarganya berusia kurang dari 40 tahun, jenis kelamin kepala keluarga perempuan, tingkat pendidikan kepala keluarga menengahtinggi, keluarga dengan kuintil kekayaan terbawah, tipe keluarga tidak utuh/tunggal, indeks pengetahuan remaja tentang NAPZA menengah, indeks pengetahuan remaja tentang HIV menengah, dan indeks pengetahuan orang tua tentang program pembangunan keluarga yang tinggi.

Berdasarkan hasil penelitian yang telah dilakukan, terdapat beberapa saran yang diberikan, yaitu sebagai berikut: 1) untuk peneliti, diharapkan penelitian lanjutan yang berkaitan dengan pengasuhan dan perlindungan anak yang terkait dengan perilaku negatif; 2) untuk masyarakat terutama yang rentan, diperlukan pendampingan melalui peningkatan pengetahuan dan lifeskills seperti pencegahan resiko terhadap NAPZA; 3) untuk keluarga, diperlukan pendampingan untuk mewujudkan ketahanan keluarga dalam mencegah perilaku NAPZA remaja; 4) untuk kepentingan program diprioritaskan perhatian pada remaja rentan yaitu remaja yang tinggal di perkotaan,berusia 20-24 tahun, jenis kelamin laki-laki,dan berpendidikan dasar, remaja yang berasal dari keluarga dengan umur kepala keluarganya berusia kurang dari 40 tahun, jenis kelamin kepala keluarga perempuan, tingkat pendidikan kepala keluarga menengah-tinggi, keluarga dengan kuintil kekayaan terbawah, tipe keluarga tidak utuh/tunggal.

\section{DAFTAR PUSTAKA}

Afandi, D., Chandra, F., Novitasari, D., Widjaja, I.R., \& Kurniawan, L. (2009). Tingkat penyalahgunaan obat dan faktor risiko di kalangan Siswa Sekolah Menengah Umum. Majalah Kedokteran Indonesia, 59(6): 266-271

Amoateng, A.Y.,\& Bahr, S.J. (1986). Religion, family, and adolescent drug use.Sociological Perspectives, 29(1): 5376.

Cavazos, R., Patricia, A., Spitznagel, E.L., Bucholz, K.K., Nurnberger, J., \& Edenberg, H.J. (2010). Predictors of sexual debut at age 16 or younger. Archives of Sexual Behavior, 39(2): 664-673.

Curtis, A.C. (2015). Defining adolescence.Journal of Adolescent and Family Health, 7(2).1-39

Day, M.M. (2008). Talking to youth about drugs: what do late adolescents say about parental strategies?.Family Relations, 57(1): 1-12.

Duvall, E.M.,\& Miller, B.C.(1985). Marriage and Family Development (Sixth Edition). New York: Harper \& Row.

Ennet, S.T., Faris, R., Foshee, V.A., Bauman, K.E., Hussong, A., Cai, L., Luz, H., Reyes, M., Hipp, R.J., \& Durant, R. (2008). The social ecology of adolescent alcohol Misuse.Child Development, 79(6): 17771791.

Hemovich, V., \& Crano, W.D. (2009). Family structure and adolescent drug use: an exploration of single-parent families. Subst Use Misuse, 44(14), 20992113.doi:10.3109/10826080902858375.

Hoffmann, J.P.\& Johnson, R.A. (1998). Anational portrait of family structure and 
adolescent drug dse.Journal of Marriage and the Family, 60(3): 633-645.

Hoffmann, J. (2002). The community context of family structure and adolescent drug use.Journal of Marriage and the Family, 64(2): 314-330.

Hovdestad, W., Shields, M., Williams, G., \& Tonmyr, L. (2015).Vulnerability within families headed by teen and young adult mothers investigated by child welfare services in Canada. Ottawa, 35(8/9), 143150

Humensky, J.L. (2010). Are adolescents with high socioeconomic status more likely to engage in alcohol and illicit drug use in early adulthood?.Substance Abuse Treatment, Prevention, and Policy, 5(19): 1-11.

Kabir, M.A., Goh, K.L., Kamal, S.M.M., \& Khan, M.M.H. (2013). Tobacco smoking and its association with illicit drug use among young men aged 15-24 years living in Urban Slums of Bangladesh.Plos One, 8(7): 1-11.

[Kemenkes] Kementerian Kesehatan. (2017). Pusat data dan Informasi Kementerian Kesehatan RI: Anti Narkoba Sedunia. Jakarta: kemekes.go,id.

Keyes, K.M., Cerda, M., Brady, J.E., Havens, J.R., \& Galea, S. (2014). Understanding the rural-urban differences in nonmedical prescription opioid use and abuse in the United States. American Journal of Public Health, 104(2): 52-59.

Klein, D.M.,\& White, J.M. (1996). Family Theories. An Introduction. Thousand Oaks. London. New Delhi: SAGE Publications. International Education and Professional Publisher.

Laoniramau, P., Laosee, OC., Somrongthong, R., Sunanta, W., \& Sitthiamorns, C. (2005).Factors affecting the experiences of drug use by adolescents in A Bangkok Slum.Southeast Asian Journal of Tropical Medicine and Public Health, 36(4): 10141019.

Lickona, T. (1991).Educating For Character: How Our Schools Can Teach Respect And Responsibility. United State of America: Bantam Book.ISBN 0-553-37052-9.

Lyold, CB. 2005. Growing Up Global: The Changing Transitions to Adulthood in Developing Countries. Washington, DC: National Academies Press. ISBN 0-30909528-X.
Malik, A.A., Nawaz, S., Tahir, A.A., Ahmed, S., Ashraf, S., Hanif, N., Aslam, J., Jamshed, I., Yawar, A., \& Malik, M.R. (2012). Knowledge and awareness of harmful effect of substance abuse among users and non-users: a cross-sectional study from Bari Imam. J Pak Med Assoc, 62(4): 412-415.

Marceau, K., Abar, CC., \& Jackson, KM. (2015). Parental knowledge is a contextual amplifier of associations of pubertal maturation and substance use. Journal Youth Adolescence, 44, 1720-1734.DOI : 10.1007/s10964-015-0335-8

Nisa, H., \& Afriani. (2015). Studi tentang pengetahuan terhadap NAPZA pada remaja di kota Banda Aceh. Laporan hasil penelitian dosen muda. Fakultas Kedokteran Universitas Syiah Kuala. [tersedia pada] file://C:/Users/User\%20Asus/Downloads/ Haiyun_laporan.pdf

Nur'artavia, M.R. (2017). Karakteristik pelajar penyalahguna NAPZA dan jenis NAPZA yang digunakan di Kota Surabaya. The Indonesian Jurnal $f$ Public Health, 12(1): 27-38

Oktarina., Hanafi, F., Budisuari, M.A. (2009). Hubungan antara karakteristik responden, keadaan wilayah dengan pengetahuan, sikap terhadap HIV/AIDS pada masyarakat Indonesia. Buletin Penelitian Sistem Kesehatan, 12(2), 362-369.

Ollalla, C., Fraguela, G., Antonio, J., \& Jorge, S. (2017). Two faces of parental support: risk and protection for antisocial youth depending on parental knowledge. Journal of Child and Family Studies, 26(1), 296305. DOI:10.1007/s10826-016-0559-6

Peter, R. (2015). Peran orang tua dalam krisis remaja. Humaniora, 6(4), 453-460.

Poole, M, \& Evans, G. (1987). Substance use: alife skills perspective. European Journal of Psychology of Education, 2(4), 403-419.

Ratnasari, Y. (2015). Hubungan pengetahuan, sikap siswa tentang bahaya narkoba dan peran keluarga terhadap upaya pencegahan narkoba (studi penelitian di SMP agus salim Semarang). Junrla Kesehatan Masyarakat Inondesia, 10(2), 90-99.

Sawyer, S.M., Azzopardi, P.S., Wickremarathne, D., \& Patton, G.C. (2018).The age of adolescence.Lancet Child Adolesc Health, 2(3), 223-228 DOI: 
http://dx.doi.org/10.1016/S23524642(18)30022-1.

Schwartz, S.J.,\& Pantin, H. (2005). Family functioning, identity, and problem behavior in Hispanic immigrant early dolescents.J Early Adolesc, 25(4): 392-420.

Turner, E.M., Turner, C.G., Yang, X., Luo, H.(2013). Gender wage differences and illicit drug use: findings from Yunnan Province. China International Journal, 11(1): 113-130.

Tutussaus, L.C., \& Balic, M.G. (2016). Relationship between healthy lifestyle and sociodemographic factors in adolescentsin catalonia: application of VISA-TEEN Questionnaire. PLOS ONE, 11(9): 1-19. DOI:10.1371/journal.pone.0163381 